\title{
Autoregulation of Bradykinin Receptors and Bradykinin-induced Prostacyclin Formation in Human Fibroblasts
}

\author{
Adelbert A. Roscher, Vincent C. Manganiello, \\ Carole L. Jelsema, and Joel Moss \\ Laboratory of Cellular Metabolism, National Heart, Lung, and \\ Blood Institute, National Institutes of Health, \\ Bethesda, Maryland 20205
}

bstract. The interaction of bradykinin (BK) with its specific receptors on intact cultured human fibroblasts results in production of prostaglandins, including prostacyclin $\left(\mathrm{PGI}_{2}\right)$, and accumulation of cyclic AMP. Incubation of cells with $1 \mu \mathrm{M}$ BK for $5 \mathrm{~min}$ at $37^{\circ} \mathrm{C}$ led to a marked reduction $(75-90 \%)$ in $\mathrm{BK}$-induced $\mathrm{PGI}_{2}$ release and in total number of $\left[{ }^{3} \mathrm{H}\right] \mathrm{BK}$-binding sites with no change in dissociation constant $(6.1$ and $7.6 \mathrm{nM}$ for control and BK-treated cells, respectively). The decrease in receptor number did not result from BK transferred from the first incubation into the binding assay. BK-induced receptor loss was temperature dependent; exposure of cells to BK at $4^{\circ} \mathrm{C}$ had little or no effect on receptor number. After incubation with $B K$ for $\cong 15 \mathrm{~min}$, further incubation in the absence of BK for $30 \mathrm{~min}$ at $37^{\circ} \mathrm{C}$ almost completely restored both receptor number and $\mathrm{BK}$-induced $\mathrm{PGI}_{2}$ release. With more prolonged exposure to $B K(>1 \mathrm{~h})$, restoration of receptors was inversely related to the length of exposure and the concentration of BK. Recovery was unaffected by cycloheximide. During prolonged incubation without removal of BK, cells began to recover receptors by $5 \mathrm{~h} ;>99 \%$ of the bradykinin initially present disappeared by $3 \mathrm{~h}$. Bacitracin greatly retarded BK disappearance and totally prevented recovery. These observations provide direct evidence that the number of BK receptors on cultured human fibroblasts can be regulated by BK itself. In addition, it appears that BKdegrading systems, by influencing local concentrations of the peptide, may play an important role in the autoregulation of BK receptors. The presence of highly active

Dr. Roscher's present address is Univ.-Kinderklinik Graz, Auenbruggerplatz, A-8036 Graz, Austria. Dr. Roscher was the recipient of a Max Kade Foundation research grant.

Received for publication 25 August 1983 and in revised form 12 April 1984.

The Journal of Clinical Investigation, Inc.

Volume 74, August 1984, 552-558 degradation systems might serve to protect target tissues from developing chronic insensitivity to BK and, perhaps, similar peptides.

\section{Introduction}

The nonapeptide (Arg-Pro-Pro-Gly-Phe-Ser-Pro-Phe-Arg) bradykinin (BK) ${ }^{1}$ has effects on a number of different tissues and cellular functions and causes, for example, vasodilation and hypotension, pain, increased intestinal motility, and chloride secretion (1-4). Moreover, recent evidence suggests a role for $\mathrm{BK}$ as a neurotransmitter (5). Alterations in the concentration of BK in human plasma have been reported in association with several clinical syndromes, including postgastrectomy-dumping syndrome, familial orthostatic syndromes, and carcinoid tumors $(4,6)$. In intact tissues, bradykinin receptor stimulation appears to initiate a series of intracellular events including activation of phospholipases $A_{2}$ and $C(7,8)$, the release of prostaglandins (9-11), and accumulation of cyclic AMP (cAMP) and cyclic guanosine monophosphate (10-14). The effects of BK on accumulation of cAMP are presumably indirect, a consequence of BK-promoted release of arachidonic acid and subsequent production of prostaglandins, which activate adenylate cyclase $(11,13,14)$. We have recently identified specific $\left[{ }^{3} \mathrm{H}\right] \mathrm{BK}$-binding sites on intact human fibroblasts that are closely linked to BK-induced $\mathrm{PGI}_{2}$ formation (15). On the basis of indirect evidence, others $(11,16)$ suggested the possible involvement of BK receptors in refractoriness and desensitization to BK. We report here that exposure of the cultured fibroblasts to BK causes disappearance or loss of specific BK receptors and that BKdegrading enzymes may play an important part in the autoregulation of these receptors, thus influencing tissue responsiveness to BK.

\section{Methods}

[2,3-Prolyl-3,4- $\left.{ }^{3} \mathrm{H}(\mathrm{N})\right] \mathrm{BK}(52 \mathrm{Ci} / \mathrm{mmol})$ and 6-keto- $\left[{ }^{3} \mathrm{H}\right]$ prostaglandin $F_{1 \alpha}\left(P F_{1 \alpha}\right)(120 \mathrm{Ci} / \mathrm{mmol})$ were purchased from New England Nuclear

1. Abbreviations used in this paper: BK, bradykinin; HPLC, high pressure liquid chromatography; $\mathrm{PGE}_{1}$ and $\mathrm{PGF}_{1 \alpha}$, prostaglandins $\mathrm{E}_{1}$ and $\mathrm{F}_{1 \alpha}$, respectively; $\mathbf{P G I}_{2}$, prostacyclin. 
(Boston, MA). $\left[{ }^{3} \mathrm{H}\right] \mathrm{BK}$ was analyzed by high pressure liquid chromatography (HPLC) using a micro-Bondapak $\mathrm{C}_{18}$ column eluted for 50 min with a mixture of $80 \%$ solution A $(0.05 \%$ trifluoroacetic acid, $0.25 \%$ triethanolamine in water) and $20 \%$ solution B $(0.05 \%$ trifluoroacetic acid, $0.25 \%$ triethanolamine, $80 \%$ acetonitrile). Unlabeled BK was purchased from Beckman Instruments, Inc. (Fullerton, CA); BK analogues from Peninsula Laboratories (Belmont, CA); cell culture medium and additives from Gibco Laboratories (Grand Island, NY); $d$, l-isoproterenol$\mathrm{HCl}$ and cycloheximide from Sigma Chemical Co. (St. Louis, MO); bacitracin from Calbiochem-Behring Corp. (San Diego, CA); bovine albumin from Armour Pharmaceutical Co. (Tarrytown, NY); 6-keto$\mathrm{PGF}_{1 \alpha}$ antiserum and standard from Seragen, Inc. (Boston, MA); dextran T-70 from Pharmacia Fine Chemicals (Piscataway, NJ). Prostaglandin $E_{1}\left(P_{1} E_{1}\right)$ was generously supplied by Dr. J. E. Pike, The Upjohn Company (Kalamazoo, MI). All other reagents were of analytical grade and obtained from commercial sources.

Stock cultures of human fibroblasts (HF-15) from a healthy newborn male were maintained as described (17). Subcultures, initiated with 1 $\times 10^{6}$ cells in $60-\mathrm{mm}$ dishes, were grown to confluence. Medium was replaced the day before cells were used. For experiments, after removal of growth medium, cells were washed and incubated at $37^{\circ} \mathrm{C}$ in Hanks' solution supplemented with $0.05 \%$ bovine albumin, minimal essential amino acid mixture, $2 \mathrm{mM}$ glutamine, and $10 \mathrm{mM}$ 4-(2-hydroxyethyl)1-piperazineethanesulfonic acid, $\mathrm{pH} 7.3$ (hereafter referred to as medium), with or without unlabeled BK for the indicated time. To remove extracellular and surface-bound BK, cells were rinsed five times at $37^{\circ} \mathrm{C}$ with $4 \mathrm{ml}$ of Hanks' solution containing $0.1 \%$ serum albumin, taking a total of $2.5 \mathrm{~min}$, after which replicate dishes of cells were used to assess specific $\left[{ }^{3} \mathrm{H}\right] \mathrm{BK}$ binding and $\mathrm{BK}$-induced $\mathrm{PGI}_{2}$ release.

For $\left[{ }^{3} \mathrm{H}\right] \mathrm{BK}$-binding studies, cell monolayers were incubated at $4^{\circ} \mathrm{C}$ in culture dishes supported on a porous stainless steel platform covered with a film of ice water in an ice bath. Cells were incubated for $15 \mathrm{~min}$ at $4^{\circ} \mathrm{C}$ in medium containing $2 \mathrm{mM}$ bacitracin. Binding was initiated by replacing this medium with $2 \mathrm{ml}$ of medium containing bacitracin and appropriate concentrations (usually $20 \mathrm{nM}$ unless otherwise stated) of $\left[{ }^{3} \mathrm{H}\right] \mathrm{BK}$ with or without $3 \mu \mathrm{M}$ unlabeled BK. After incubation (usually $2 \mathrm{~h}$ ) at $4^{\circ} \mathrm{C}$, medium was removed and cells were rapidly rinsed four times with a total of $20 \mathrm{ml}$ ice-cold modified Hanks' solution containing $0.2 \%$ bovine serum albumin ( $\mathrm{pH} 7.3$ ). Cells were then rinsed twice with ice-cold Dulbecco's phosphate-buffered saline, incubated with $2 \mathrm{ml}$ of $0.1 \%$ trypsin $\left(10 \mathrm{~min}, 37^{\circ} \mathrm{C}\right)$, and quantitatively transferred to vials for radioassay after addition of $15 \mathrm{ml}$ of Aquasol (New England Nuclear). Specific binding of $\left[{ }^{3} \mathrm{H}\right] \mathrm{BK}$ was defined as the difference between total $\left[{ }^{3} \mathrm{H}\right] \mathrm{BK}$ bound and that bound in the presence of $3 \mu \mathrm{M}$ unlabeled BK (nonspecific binding) and usually represented $>95 \%$ of the total $\left[{ }^{3} \mathrm{H}\right] \mathrm{BK}$ bound.

To assess BK-induced $\mathrm{PGI}_{2}$ release, cells were incubated for $5 \mathrm{~min}$ at $37^{\circ} \mathrm{C}$ in Hanks' solution with or without $1 \mu \mathrm{M} \mathrm{BK}$. $\mathrm{PGI}_{2}$ in the medium was determined as its metabolite 6-keto- $\mathrm{PGF}_{1 \alpha}$ by a modification of the radioimmunoassay of Jaffe et al. (18). Each assay contained 100 $\mu \mathrm{l}$ of medium or standard (10-2,000 pg), $50 \mu \mathrm{l}$ of 6-keto-PGF ${ }_{1 \alpha}(7,000$ $\mathrm{cpm}$ ), $50 \mu \mathrm{l}$ of antiserum (diluted such that $\sim 40 \%$ of the radioligand was bound), and $0.1 \%$ of gelatin in a total volume of $400 \mu \mathrm{l}$ of $10 \mathrm{mM}$ Tris/ $150 \mathrm{mM} \mathrm{NaCl}, \mathrm{pH} 7.4$. After incubation for $16 \mathrm{~h}$ at $4^{\circ} \mathrm{C}, 500 \mu \mathrm{l}$ of an ice-cold $0.5 \%$ charcoal $/ 0.05 \%$ dextran mixture was added and tubes were centrifuged $\left(1,000 \mathrm{~g}, 10 \mathrm{~min}, 4^{\circ} \mathrm{C}\right)$. Supernatants containing antibody-bound 6-keto- $\left[{ }^{3} \mathrm{H}\right] \mathrm{PGF}_{1 \alpha}$ were decanted into vials for radioassay after addition of $10 \mathrm{ml}$ of Aquasol.

BK remaining in the medium after incubation with fibroblasts was estimated by using a receptor-binding assay. BK (and closely related analogues) but not BK degradation products compete with $\left[{ }^{3} \mathrm{H}\right] \mathrm{BK}$ for binding by fibroblasts in proportion to their biological activity (15). Samples $(1.5 \mathrm{ml})$ of used incubation medium containing BK or appropriate standards $(0.5-1,000 \mathrm{ng} / \mathrm{ml} \mathrm{BK})$ were diluted with $0.5 \mathrm{ml}$ of buffer containing $8 \mathrm{mM}$ bacitracin and frozen immediately. Samples $(2 \mathrm{ml})$ were thawed on ice, diluted if necessary, mixed with $100 \mu \mathrm{l}$ of $100 \mathrm{nM}$ $\left[{ }^{3} \mathrm{H}\right] \mathrm{BK}$ and incubated with fibroblasts to determine specific $\left[{ }^{3} \mathrm{H}\right] \mathrm{BK}$ binding. $\mathrm{BK}$ remaining in the used medium was calculated from a standard plot of percentage of $\left[{ }^{3} \mathrm{H}\right] \mathrm{BK}$ specifically bound vs. BK concentration.

\section{Results}

In cultured human fibroblasts, $\mathrm{PGE}_{1}$ and isoproterenol, acting through their respective receptors, increase adenylate cyclase activity and thereby cause accumulation of cAMP (16). BK presumably increases the cAMP content of these and other cells indirectly as a consequence of BK-induced prostaglandin production $(10,11,13,14)$. Incubation of fibroblasts with $1 \mu \mathrm{M}$ $\mathrm{BK}$ at $37^{\circ} \mathrm{C}$ markedly reduced the rise in cAMP produced by a subsequent 5-min exposure to $\mathrm{BK}$ without altering responses to $\mathrm{PGE}_{1}$ or isoproterenol (Table I).

In an earlier study, Scatchard analysis of equilibrium binding of $\left[{ }^{3} \mathrm{H}\right] \mathrm{BK}$ to human fibroblasts at $4{ }^{\circ} \mathrm{C}$ indicated a dissociation constant $\left(K_{\mathrm{d}}\right)$ of $4.6 \pm 0.1 \mathrm{nM}$ and maximum binding $\left(B_{\max }\right)$ of $230 \pm 18 \mathrm{fmol}\left[{ }^{3} \mathrm{H}\right] \mathrm{BK}$ bound $/ \mathrm{mg}$ protein (mean $\left.\pm \mathrm{SE}, n=4\right)$ (15). BK-induced $\mathrm{PGI}_{2}$ release and specific binding of $\left[{ }^{3} \mathrm{H}\right] \mathrm{BK}$ were decreased by prior incubation of fibroblasts with $\mathrm{BK}$ at $37^{\circ} \mathrm{C}$. Both were reduced maximally, $\sim 75 \%$, after $5-10 \mathrm{~min}$ of exposure to $1 \mu \mathrm{M} \mathrm{BK}$ and remained at this level for $60 \mathrm{~min}$ (Fig. 1). (In other experiments, both were reduced by $75-90 \%$ in $10 \mathrm{~min}$.) The apparent loss of receptors was temperature dependent and observed when cells were incubated with BK at

Table I. Effect of Prior Incubation with $B K$ on cAMP Accumulation in Response to $B K, P G E_{l}$, and Isoproterenol

\begin{tabular}{lcc}
\hline & \multicolumn{2}{c}{ cAMP content } \\
\cline { 2 - 3 } Additions for $5 \mathrm{~min}$ & No BK & $1 \mu \mathrm{M} \mathrm{BK}$ \\
\hline & pmol/mg protein & pmol/mg protein \\
None & $24 \pm 2.6$ & $24 \pm 2.6$ \\
Bradykinin, 1 $\mu \mathrm{M}$ & $193 \pm 4.9$ & $41 \pm 1.8$ \\
PGE $1,1 \mu \mathrm{M}$ & $911 \pm 32$ & $1,180 \pm 54$ \\
Isoproterenol, $1 \mu \mathrm{M}$ & $124 \pm 2.0$ & $141 \pm 3.4$ \\
\hline
\end{tabular}

Cells were incubated with or without $1 \mu \mathrm{M}$ BK for $15 \mathrm{~min}$ at $37^{\circ} \mathrm{C}$, then washed and incubated for $5 \mathrm{~min}$ with additions as indicated. Medium was rapidly replaced with ice-cold 5\% trichloroacetic acid. cAMP in the cell extracts was determined by radioimmunoassay (New England Nuclear) after removal of trichloroacetic acid with trioctylamine/Freon (19). Data are means \pm SEM of values from triplicate incubations. 


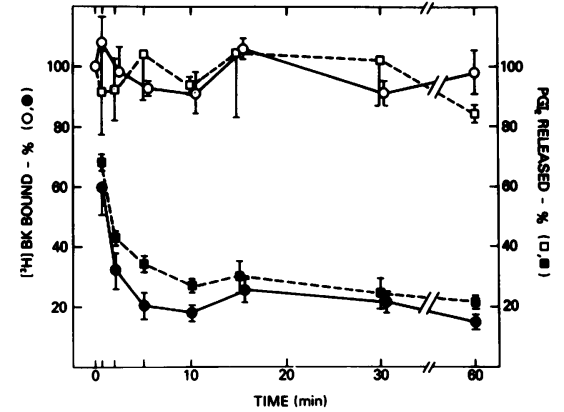

Figure 1. Effect of incubation with BK on subsequent $\left[{ }^{3} \mathrm{H}\right] \mathrm{BK}$ binding and $\mathrm{BK}$-induced $\mathrm{PGI}_{2}$ release by fibroblasts. Cells were incubated at $37^{\circ} \mathrm{C}$ in medium with (०. $\square$ ) or without $(0 . \square) 1 \mu \mathrm{M}$ BK, then washed at $37^{\circ} \mathrm{C}$ and $\left[{ }^{3} \mathrm{H}\right] \mathrm{BK}$ binding $(\mathrm{O}, \bullet)$ or $\mathrm{BK}$-induced $\mathrm{PGI}_{2}$ release ( $\square . \square)$ was assayed as described in Methods. Percentage of initial $\left[{ }^{3} \mathrm{H}\right] \mathrm{BK}$ binding $(275 \pm 5 \mathrm{fmol} / \mathrm{mg}$ protein $=100)$ or of initial BK-induced $\mathrm{PGI}_{2}$ release $(11.5 \pm 2 \mathrm{ng} /$ dish $=100)$ is plotted as a function of time of prior incubation with BK. Data are means \pm SD of values from triplicate incubations.

$37^{\circ}$ and not at $4^{\circ} \mathrm{C}$. Exposure of cells to $1 \mu \mathrm{M}$ BK for $30 \mathrm{~min}$ at $4^{\circ} \mathrm{C}$ (followed by washing at $37^{\circ} \mathrm{C}$ as described in Methods) reduced $\left[{ }^{3} \mathrm{H}\right] \mathrm{BK}$ binding only by $10 \%$ (from $220 \pm 8 \mathrm{fmol} / \mathrm{mg}$ protein in control cells incubated at $37^{\circ} \mathrm{C}$ without $\mathrm{BK}$ to $204 \pm \mathrm{fmol} / \mathrm{mg}$ protein in BK-treated cells) in contrast to the much greater decrease in binding of $\left[{ }^{3} \mathrm{H}\right] \mathrm{BK}$ observed after incubation with $\mathrm{BK}$ at $37^{\circ} \mathrm{C}$ (to $59 \pm 11 \mathrm{fmol} / \mathrm{mg}$ protein). The reduction in $\left[{ }^{3} \mathrm{H}\right] \mathrm{BK}$ binding was dependent on the concentration of BK present during a 15-min incubation and closely

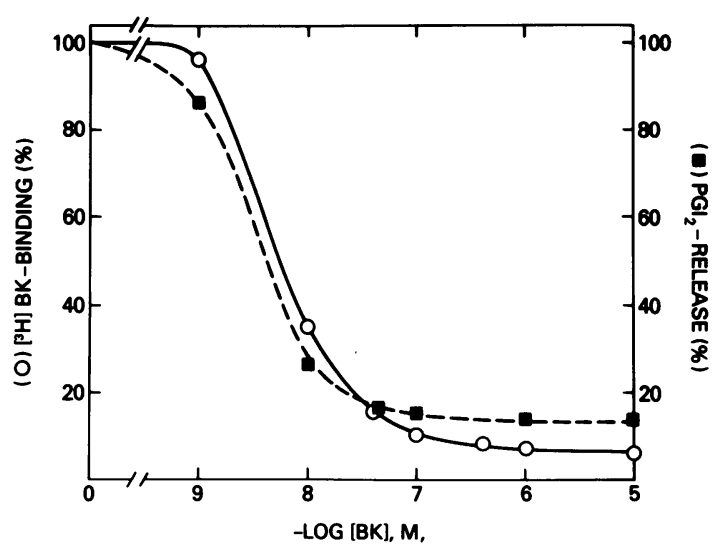

Figure 2. Effect of $\mathrm{BK}$ concentration during initial incubation on subsequent $\left[{ }^{3} \mathrm{H}\right] \mathrm{BK}$ binding and $\mathrm{BK}$-induced $\mathrm{PGI}_{2}$ release. Cells were incubated for $15 \mathrm{~min}$ at $37^{\circ} \mathrm{C}$ with the indicated concentration of BK, then washed and specific $\left[{ }^{3} \mathrm{H}\right] \mathrm{BK}$ binding $(\mathrm{O})$ or BK-induced release of $\mathrm{PGI}_{2}(\mathrm{a})$ was assayed. Control $\left[{ }^{3} \mathrm{H}\right] \mathrm{BK}$ binding $(100 \%)$ was $198 \mathrm{fmol} / \mathrm{mg}$ protein, and $\mathrm{PGI}_{2}$ release was $14.5 \mathrm{ng} / \mathrm{dish}$. Data, reported as in Fig. 1, are means of values from triplicate incubations. SD were in the range as shown in Fig. 1.

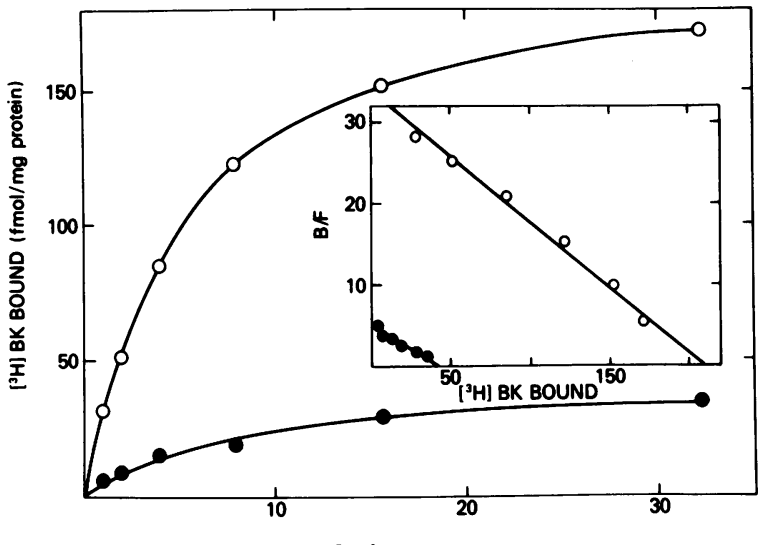

$\left[{ }^{3} \mathrm{H}\right]$ BK $(\mathrm{nM})$

Figure 3. Binding of $\left[{ }^{3} \mathrm{H}\right] \mathrm{BK}$ by fibroblasts before and after incubation with BK. Cells were incubated with ( $(\bullet)$ or without (0) $1 \mu \mathrm{M}$ BK for $15 \mathrm{~min}$ at $37^{\circ} \mathrm{C}$, washed, and then incubated with the indicated concentrations of $\left[{ }^{3} \mathrm{H}\right] \mathrm{BK}$ with or without $3 \mu \mathrm{M}$ unlabeled BK for 2 $\mathrm{h}$ at $4^{\circ} \mathrm{C}$ to determine specific binding. (Inset) Scatchard plot of the data. Lines were computed by linear regression analysis $(r=0.99$ and 0.93 , respectively) B/F, bound/free. In control cells, the $K_{\mathrm{d}}$ was $6.1 \mathrm{nM}$ and $B_{\max } 211 \mathrm{fmol} / \mathrm{mg}$ protein; respective values for the BKtreated cells were $7.6 \mathrm{nM}$ and $42 \mathrm{fmol} / \mathrm{mg}$ protein. Data are means of values from triplicate assays.

paralleled the reduction in BK-stimulated $\mathrm{PGI}_{2}$ release (Fig. 2). The concentration that caused a half-maximal reduction $\left(\mathrm{ED}_{50}\right)$ in both was 4-6 $\mathrm{nM}$. The reduction in specific $\left[{ }^{3} \mathrm{H}\right] \mathrm{BK}$ binding resulting from incubation of cells with $\mathrm{BK}$ for 15 min appeared to reflect a decrease in binding capacity without any significant alteration in affinity (Fig. 3).

The apparent loss of receptors at $37^{\circ} \mathrm{C}$ is not simply due to carry-over of free or bound BK from the first incubation. After incubation with saturating $(20 \mathrm{nM})\left[{ }^{3} \mathrm{H}\right] \mathrm{BK}$ at $4^{\circ} \mathrm{C}$ for as long as $2 \mathrm{~h}$ and washing at $4^{\circ} \mathrm{C}$ (which serves to dilute and remove free BK with little or no loss of cell-bound ligand [15]), maximal binding of $\left[{ }^{3} \mathrm{H}\right] \mathrm{BK}$ was $\geq 200 \mathrm{fmol} / \mathrm{mg}$ protein. Incubation $\left(10 \mathrm{~min}, 4^{\circ} \mathrm{C}\right)$ with acetic acid $(0.2 \mathrm{~N}, \mathrm{pH} 2.8)$ released $>90 \%(93 \pm 3, n=4)$ of the radioactivity specifically bound to the cells (20). Virtually all of this acid-extracted material bound to CM-Sephadex and eluted as authentic BK (15). This indicates that at $4^{\circ} \mathrm{C}$ most of the ligand is surface-bound and represents intact BK, although as discussed by Wiley and Cunningham (25) the acid extraction procedure is not entirely quantitative and could reflect extraction of a small amount of material not bound to the cell surface. Of the BK specifically bound during incubation of cells with saturating concentrations of $\left[{ }^{3} \mathrm{H}\right] \mathrm{BK}$ $(20 \mathrm{nM})$ at $4^{\circ} \mathrm{C} \mathrm{(236} \mathrm{fmol} / \mathrm{mg}$ protein $),>90 \%$ was released $(218$ fmol/mg protein) by washing at $37^{\circ} \mathrm{C}$ as described in Methods. Further incubation with excess, unlabeled BK at either $4^{\circ}$ or $37^{\circ} \mathrm{C}$ released virtually no radioactivity, suggesting that washes at $37^{\circ} \mathrm{C}$ were efficient in removing readily accessible, presumably 
surface-bound BK and that residual radiolabel ( $\sim 200$ cpm representing $\sim 18 \mathrm{fmol} / \mathrm{mg}$ protein) was not surface-bound but presumably internalized. In other experiments, cells were incubated with $20 \mathrm{nM}\left[{ }^{3} \mathrm{H}\right] \mathrm{BK}$ for $15 \mathrm{~min}$ at $37^{\circ} \mathrm{C}$, then washed at $37^{\circ} \mathrm{C}$ as described in Methods or in the same manner at $4^{\circ} \mathrm{C}$. Cells were then incubated $\left(10 \mathrm{~min}, 4^{\circ} \mathrm{C}\right)$ with acetic acid $(0.2$ $\mathrm{N}, \mathrm{pH} 2.8$ ). After washing at $37^{\circ} \mathrm{C}$ and incubating with acetic acid, released radioactivity represented only $\sim 6 \mathrm{fmol} / \mathrm{mg}$ protein, $<10 \%$ of that released from cells washed at $4^{\circ} \mathrm{C}$. Since maximal binding was $\geq 200 \mathrm{fmol} / \mathrm{mg}$ protein, this amount of residual BK, even if surface-bound, could not account for the observed $90 \%$ reduction in $\left[{ }^{3} \mathrm{H}\right] \mathrm{BK}$ binding resulting from incubation with $20 \mathrm{nM}$ BK (Fig. 2). After acid treatment, the remaining ${ }^{3} \mathrm{H}$ (presumably internalized peptides) was completely (>95\%) extracted with ethanol. Radioactivity in the ethanol extract, analyzed by HPLC as described in Methods, was associated entirely with altered/degraded products of BK (data not shown). This indicates that after incubation and washing at $37^{\circ} \mathrm{C}$ only a negligible amount of radiolabel remains susceptible to extraction with acetic acid (and presumably is bound to the cell surface); residual radiolabel represents both internalized and degraded/altered products of BK.

With cells that had been exposed to $1 \mu \mathrm{M}$ BK for $15 \mathrm{~min}$, incubation at $37^{\circ} \mathrm{C}$ for $30 \mathrm{~min}$ after removal of BK restored $\left[{ }^{3} \mathrm{H}\right] \mathrm{BK}$ binding and $\mathrm{BK}$-induced $\mathrm{PGI}_{2}$ release almost completely (Fig. 4). Exposure of cells for $15 \mathrm{~min}$ to $0.03,0.3$, or $3 \mu \mathrm{M} \mathrm{BK}$ caused $\sim 80 \%$ loss of receptors, and restoration of receptor number was virtually complete after a subsequent 60 -min incubation (Fig. 5). After incubation with 0.3 or $3 \mu \mathrm{M}$ BK for 60 min or more, however, a further 60 -min incubation resulted in only partial restoration of $\left[{ }^{3} \mathrm{H}\right] \mathrm{BK}$ binding (Fig. 5). In other experiments, BK was not removed and cells began to recover [ ${ }^{3} \mathrm{H}$ ]BK-binding sites by $3 \mathrm{~h}$; binding was restored to $\sim 50 \%$ of maximal by the eighth hour (Fig. $6 \mathrm{~B}$ ). In this experiment, $>99 \%$ of the BK initially present disappeared in $3 \mathrm{~h}$ and by $5 \mathrm{~h}$ no BK was detectable (Fig. $6 \mathrm{~A}$ ). When bacitracin was present, the BK concentration was still $>100 \mathrm{nM}$ after $8 \mathrm{~h}$ and there was no recovery of $\left[{ }^{3} \mathrm{H}\right] \mathrm{BK}$-binding sites. The nature of the presumed fibroblast BK-degrading systems has not been determined. Degradation, however, does not occur in the medium as a result of peptidase secretion or leakage (unpublished observations). Inhibitor experiments and HPLC analysis of the degradation products of BK indicate that neither kininase I nor kininase II is likely to be involved (15). During incubation at $37^{\circ} \mathrm{C}$ with human fibroblasts, immunoreactive substance $P$ also disappeared, suggesting that the presumed degradative system is not specific for bradykinin (data not shown).

\section{Discussion}

As reported here, incubation of human fibroblasts with BK at $37^{\circ} \mathrm{C}$ rapidly caused a decrease in specific $\left[{ }^{3} \mathrm{H}\right] \mathrm{BK}$ binding; the

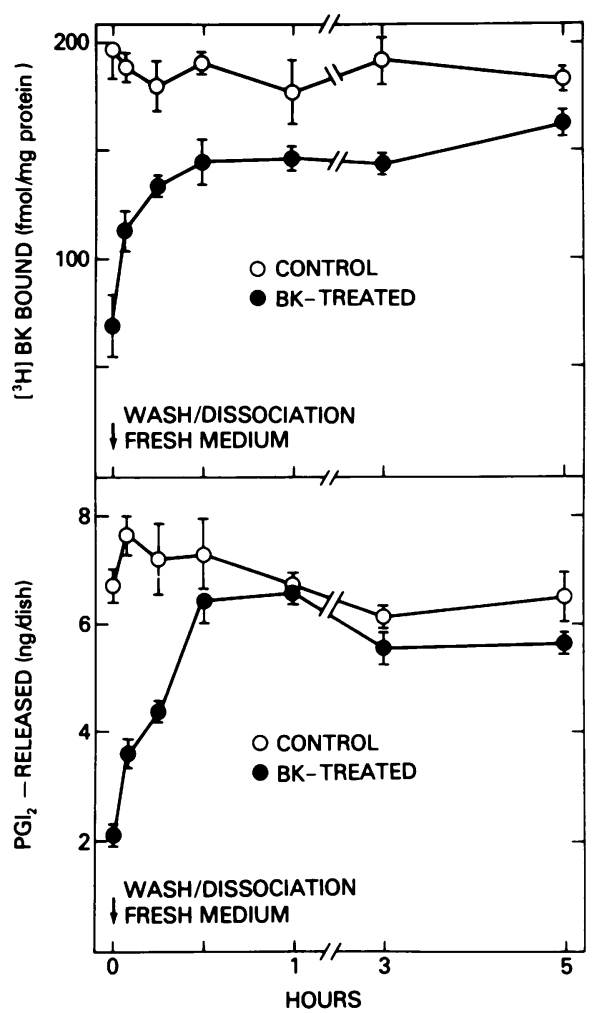

Figure 4. Recovery of specific $\left[{ }^{3} \mathrm{H}\right] \mathrm{BK}$ binding and $\mathrm{BK}$-induced $\mathrm{PGI}_{2}$ release after brief exposure to BK. Cells were incubated with $(\bullet)$ or without (O) $1 \mu \mathrm{M} \mathrm{BK}$ for $15 \mathrm{~min}$ at $37^{\circ} \mathrm{C}$, washed, and further incubated at $37^{\circ} \mathrm{C}$ in $2 \mathrm{ml}$ of fresh medium. At the indicated time, specific $\left[{ }^{3} \mathrm{H}\right] \mathrm{BK}$ binding (upper) and the $\mathrm{BK}$-induced $\mathrm{PGI}_{2}$ release (lower) were measured. Data are means $\pm \mathrm{SD}$ of values from triplicate incubations.

number of binding sites was reduced but their affinity for BK was apparently unaltered. The decrease in binding sites was closely paralleled by a decrease in $\mathrm{BK}$-induced $\mathrm{PGI}_{2}$ production, indicating that these high affinity specific binding sites have the functional characteristics of receptors. In addition, it would appear that in the fibroblasts virtually all BK receptors are linked to the cellular effector system, i.e., there is no significant fraction of "reserve" or "spare" receptors.

Reduction in number of BK receptors and in BK-induced $\mathrm{PGI}_{2}$ release exhibited the same dependence on $\mathrm{BK}$ concentration. Half-maximal decreases in both were produced with $\sim 6$ $n M$ BK, a concentration approximating the $K_{\mathrm{d}}$ for the BK receptor in these cells. With several BK analogues, the rank order of potency in causing receptor loss (21) was similar to the order of potency in competing for specific $\left[{ }^{3} \mathrm{H}\right] \mathrm{BK}$ binding or stimulating $\mathrm{PGI}_{2}$ production (15). Thus, there is close correlation between agonist occupancy of the $\mathrm{BK}$ receptor and receptor loss. In addition to receptor occupancy, however, a further tem- 


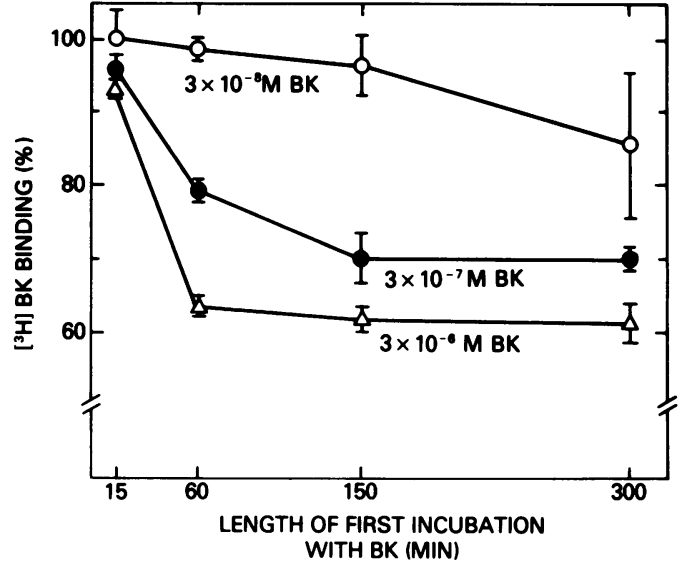

Figure 5. Effect of BK concentration and of length of incubation with BK on the recovery of BK receptors. Cells were incubated at $37^{\circ} \mathrm{C}$ without or with $0.03(0), 0.3(\bullet)$, or $3(\Delta) \mu \mathrm{M}$ BK. At the indicated time, cells were washed and then incubated for $60 \mathrm{~min}$ at $37^{\circ} \mathrm{C}$ with $2 \mathrm{ml}$ of fresh medium before measurement of specific $\left[{ }^{3} \mathrm{H}\right]-\mathrm{BK}$ binding. Specific $\left[{ }^{3} \mathrm{H}\right] \mathrm{BK}$ binding by cells incubated with BK for the indicated time is reported as percentage of that by cells incubated for the same period without BK and subsequently treated in the same way. These values ranged from 253 to $314 \mathrm{fmol} / \mathrm{mg}$ protein. Data are means \pm SD of values from triplicate incubations.

perature-dependent step(s) must be involved, since cells incubated with $\mathrm{BK}$ at $4^{\circ} \mathrm{C}$ rather than $37^{\circ} \mathrm{C}$, although they bound $B K$, did not exhibit a significant reduction in receptor number or in $\mathrm{BK}$-induced $\mathrm{PGI}_{2}$ release. As incubation of cells with $\mathrm{BK}$ did not alter their responsiveness to $\mathrm{PGE}_{1}$ or isoproterenol, the loss or disappearance of BK-binding sites appears to represent specific autoregulation of the BK receptor, i.e., homologous desensitization (22).

Because of the extremely rapid dissociation of BK from its receptors at $37^{\circ} \mathrm{C}(15)$, it was possible to remove essentially all of the BK present in the medium and bound to the cell surface during the initial "desensitizing" incubation simply with five washes at $37^{\circ} \mathrm{C}$ before assay of $\left[{ }^{3} \mathrm{H}\right] \mathrm{BK}$ binding at $4^{\circ} \mathrm{C}$. The efficacy of this procedure was documented by several types of evidence. First, although the fibroblasts bind $\mathrm{BK}$ at $4^{\circ} \mathrm{C}$, this does not lead to a reduction in receptor number. Any ligand not removed by washing at $37^{\circ} \mathrm{C}$ should have decreased the subsequent binding of $\left[{ }^{3} \mathrm{H}\right] \mathrm{BK}$. In addition, retained ligand would be expected to increase the apparent affinity for BK (23), whereas the reduction in binding capacity induced by incubation of the cells with $\mathrm{BK}$ at $37^{\circ} \mathrm{C}$ was associated with little or no change in $K_{d}$. Direct measurement of surface-bound (acid-released) radioligand showed that the amount remaining after cells were washed at $37^{\circ} \mathrm{C}$ could account for only a small fraction $(\sim 3 \%)$ of the reduction in binding sites. This experiment also revealed that after incubation at $37^{\circ} \mathrm{C}$ part of the cell-associated $\left[{ }^{3} \mathrm{H}\right]$ is not released with acid and is presumably intracellular.

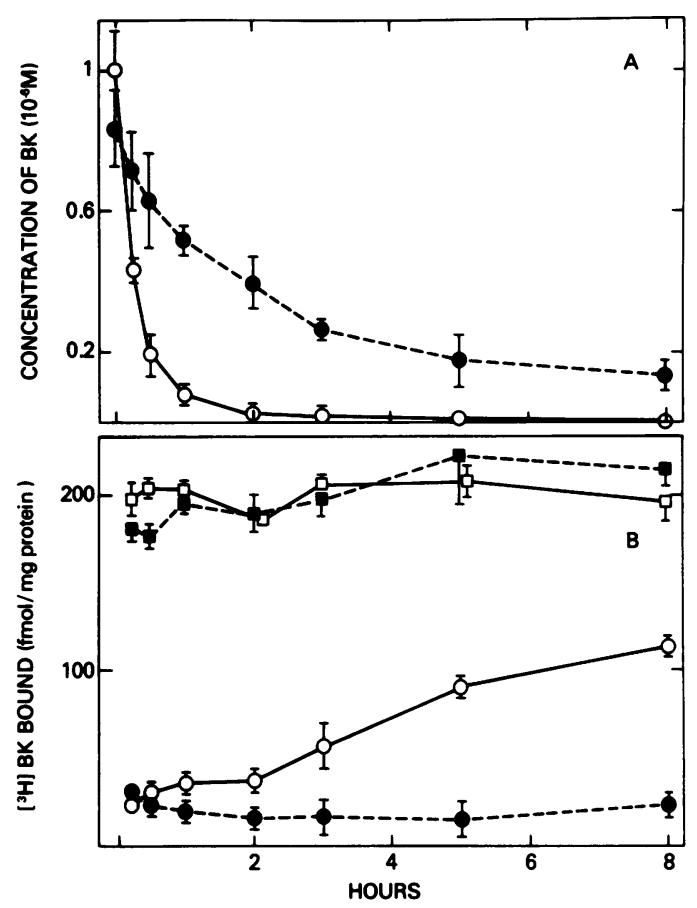

Figure 6. BK degradation and specific $\left[{ }^{3} \mathrm{H}\right] \mathrm{BK}$ binding during long term incubation with BK with and without bacitracin. Cells were in-

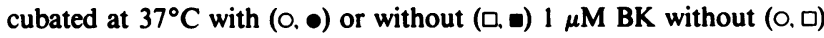
or with (๑. 2 mM bacitracin. Medium was collected at the indicated time for assay of intact BK remaining as described in Methods $(A)$. Points at 3,5 , and $8 \mathrm{~h}$ represent concentrations of BK below the detection limit of the assay (i.e., $0.5 \mathrm{ng} / \mathrm{ml}$ ). After removal of medium, cells were washed and specific $\left[{ }^{3} \mathrm{H}\right] \mathrm{BK}$ binding was determined $(B)$. Data are presented as means \pm SD of values from triplicate incubations.

This material consisted exclusively of altered/degraded products of BK.

BK-induced receptor loss and restoration appear to involve several processes. After brief (15-30 $\mathrm{min}$ ) exposure to BK, restoration of receptors was essentially complete within $30 \mathrm{~min}$ after removal of BK. The reappearance of BK receptors was accompanied by a parallel recovery in $\mathrm{BK}$-induced $\mathrm{PGI}_{2}$ release, indicating a functional coupling of the restored receptors with prostaglandin synthesis. In contrast to the relatively rapid and complete restoration of receptors after brief incubation (15 min) with BK, only partial recovery of binding occurred when cells had been exposed to BK for $>1 \mathrm{~h}$. Recovery was inversely related to the concentration of $\mathrm{BK}$ as well as the duration of exposure. During prolonged incubation of fibroblasts without removal of BK, partial recovery of BK receptors ( 40-60\%) was observed within $6 \mathrm{~h}$. Under these conditions, however, substantial degradation of BK occurred so that within 3-5 h the concentration of BK was $<0.5 \mathrm{nM}$. Similar recovery of responsiveness during incubation with angiotensin II and substance 
$P$ as well as BK has been reported (16). Bacitracin, which had no effect on the binding of BK to cells or on the time course of BK-induced down-regulation, markedly retarded BK degradation and completely prevented recovery of BK receptors during an 8-h incubation. Similarly, putative BK receptors in rat uterus were reportedly decreased after infusion of the kininase II inhibitor Captopril (24). Processes other than peptide degradation appear to influence the rate and extent of receptor reappearance on the cell surface, since the full complement of receptors was not restored even several hours after removal or complete destruction of BK in the incubation medium. It is of interest that recovery of receptors, after either brief or prolonged exposure to BK, was not inhibited by cycloheximide (21).

The observations reported here might be described by a model in which BK receptors cycle between active (accessible to the peptide and coupled to $\mathrm{PGI}_{2}$ production) and inactive states and that prolonged receptor occupancy leads to incomplete reactivation of inactive receptors. Although the molecular mechanisms underlying these phenomena remain to be elucidated, the temperature-dependent accumulation of BK degradation products in an apparently intracellular compartment suggests that internalization of a ligand-receptor complex may be involved as is the case with several other hormones (25-27). In the sense that BK degradation minimizes both the concentration to which cells are exposed and the duration of exposure, it could be of major importance in regulating the number of functional receptors and thereby the responsiveness of cells to the peptide. The presence of highly active degradation systems might serve to protect target tissues from developing a chronic insensitivity to BK and perhaps similar peptides. In addition to providing direct evidence that BK induces the homologous desensitization of its specific receptor as do many other peptide hormones $(22,26)$, our experiments are consistent with the view that autoregulation of the BK receptor and its biological function is controlled by peptide-degrading systems. These findings could prove useful in understanding the impact of therapeutic interventions aimed at altering plasma or tissue content of BK (28) and might also serve as a model for the regulation of receptors for other hormones (e.g., opioid peptides, histamine) that are rapidly degraded in their target tissues.

\section{Acknowledgments}

We thank Dr. J. Pisano for teaching one of us (Dr. Roscher) peptide HPLC analysis and for use of his laboratory facilities, Dr. A. Saria for measurements of immunoreactive Substance P, and Dr. M. Vaughan for helpful discussions during the course of this work. We also thank Mrs. B. E. Hom and Mrs. D. M. Sherwood for excellent technical and secretarial assistance, respectively.

\section{References}

1. Juan, H., and F. Lembeck. 1974. Action of peptides and other algesic agents on paravascular pain receptors of the isolated perfused rabbit ear. Naunyn-Schmiedeberg's Arch. Pharmakol. 283:151-164.
2. Cuthbert, A. W., and H. S. Margolius. 1982. Kinins stimulate net chloride secretion by the rat colon. Br. J. Pharmacol. 75:587-588.

3. Manning, D. C., S. H. Snyder, T. F. Kachur, R. J. Miller, and M. Field. 1982. Bradykinin receptor-mediated chloride secretion in intestinal function. Nature (Lond.) 299:256-259.

4. Regoli, D., and J. Barabe. 1980. Pharmacology of bradykinin and related kinins. J. Pharmacol. Rev. 32:1-45.

5. Correa, F. M. A., R. B. Innis, G. R. Uhl, and S. H. Snyder. 1979. Bradykinin-like immunoreactive neuronal system localized histochemically in rat brain. Proc. Natl. Acad. Sci. USA. 76:1489-1493.

6. Streeten, D. M. P., L. P. Kerr, C. B. Kerr, J. C. Prior, and T. G. Dalakos. 1972. Hyperbradykininism: A new orthostatic syndrome. Lancet. II: 1048-1053.

7. Newcombe, D. S., J. V. Fahey, and Y. Ishikawa. 1977. Hydrocortisone inhibition of the bradykinin activation of human synovial fibroblasts. Prostaglandins. 13:235-244.

8. Bell, R. J., N. J. Baenzinger, and P. W. Majerus. 1980. Bradykininstimulated release of arachidonate from phosphatidylinositol in mouse fibrosarcoma cells. Prostaglandins. 20:269-274.

9. McGiff, J. C., H. D. Itskovitz, N. A. Terragno, and P. Y. K. Wong. 1976. Modulation and mediation of the action of the renal kallikrein-kinin system by prostaglandins. Fed. Proc. 35:175-180.

10. Hong, S. C., and L. Levine. 1976. Stimulation of prostaglandin synthesis by bradykinin and thrombin and their mechanisms of action on MC5-5 fibroblasts. J. Biol. Chem. 251:5814-5816.

11. Fahey, J. V., C. P. Ciosek, Jr. and D. S. Newcombe. 1977. Human synovial fibroblasts. The relationships between cyclic AMP, bradykinin and prostaglandins. Agents Actions. 7:255-264.

12. Stoner, J., V. C. Manganiello, and M. Vaughan, 1973. Effects of bradykinin on cyclic AMP and cyclic GMP in lung slices. Proc. Natl. Acad. Sci. USA. 70:3830-3833.

13. Moncada, S., K. M. Mullane, and J. R. Vane. 1979. Prostacyclin release by bradykinin in vivo. Br. J. Pharmacol. 66:969-979.

14. Bareis, I. L., V. C. Manganiello, F. Hirata, M. Vaughan, and J. Axelrod. 1983. Bradykinin stimulates phospholipid methylation, calcium influx, prostaglandin formation and cAMP accumulation in human fibroblasts. Proc. Natl. Acad. Sci. USA. 80:2514-2518.

15. Roscher, A. A., V. C. Manganiello, C. L. Jelsema, and J. Moss. 1983. Receptors for bradykinin in intact cultured human fibroblasts. Identification and characterization by direct binding study. J. Clin. Invest. 72:626-635.

16. Drouin, J. N., S. A. St.-Pierre, and D. Regoli. 1979. Receptors for bradykinin and kallidin. Can. J. Physiol. Pharmacol. 57:375-379.

17. Manganiello, V. C., and J. Breslow. 1974. Effects of prostaglandin $E_{1}$ and isoproterenol on cyclic AMP content of human fibroblasts modified by time and cell density in subculture. Biochim. Biophys. Acta. 362:509-520.

18. Jaffe, B. M., I. W. Smith, W. T. Newton, and C. W. Parker. 1971. Radioimmunoassay for prostaglandins. Science (Wash. DC). 171:494-496.

19. Riss, T. L., N. L. Zorich, M. D. Williams, and A. Richardson. 1980. A comparison of the efficiency of nucleotide extraction by several procedures and the analysis of nucleotides from extracts of liver and isolated hepatocytes by HPLC. J. Liquid Chromatogr. 3:133-158. 
20. Haigler, H. T., F. R. Maxfield, M. C. Willingham, and I. Pastan. 1980. Dansylcadaverine inhibits internalization of ${ }^{125}$ I-epidermal growth factor in BALB 3T3 cells. J. Biol. Chem. 255:1239-1241.

21. Roscher, A. A., V. C. Manganiello, C. L. Jelsema, J. Moss, and M. Vaughan. 1983. Regulation by bradykinin of its receptor and of receptor-mediated prostacyclin formation in cultured human fibroblasts. Trans. Assoc. Am. Phys. XCVI:175-181.

22. Lefkowitz, R. J., M. R. Wessels, and J. M. Stadel. 1980. Hormones, receptors and cyclic AMP: Their role in target cell refractoriness. In Current Topics in Cellular Regulation. B. L. Horecker and E. R. Stadtman, editors. Academic Press, Inc., New York. 205-230.

23. Karliner, J. S., H. J. Motulsky, and P. A. Insel. 1981. Apparent "down-regulation" of human platelet alpha ${ }_{2}$-adrenergic receptors due to retained agonist. Mol. Pharmacol. 21:36-43.
24. Yasujuma, M., P. G. Matthews, and C. I. Johnston. 1981. Regulation of uterine smooth muscle bradykinin receptors by bradykinin levels and angiotensin converting enzyme inhibitor in the rat. Clin. Exp. Pharmacol. Physiol. 8:515-518.

25. Wiley, H. S., and D. D. Cunningham. 1982. The endocytic rate constant. J. Biol. Chem. 257:4222-4229.

26. Catt, K. J., J. P. Harwood, G. Aguilera, and M. L. Dufau. 1979. Hormonal regulation of peptide receptors and target cell responses. Nature (Lond.) 280:109-116.

27. Gorden, P., J.-L. Carpentier, J.-Y. Fan, and L. Orci. 1982. Receptor mediated endocytosis of polypeptide hormones: Mechanism and significance. Metab. Clin. Exp. 31:664-669.

28. Williams, G. H., and N. K. Hollenberg. 1977. Accentuated vascular and endocrine response to SQ 20881 in hypertension. $N$. Engl. $J$. Med. 297:184-188. 